\title{
Omolade Adunbi
}

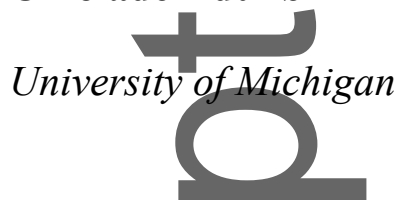

The Facebook President: Oil, Citizenship, and the Social Mediation of Politics in

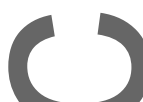

Nigeria

On June 28, 2010, Nigerian President Jonathan announced that he had set up a Facebook page. Within a fery days, his first post garnered 1,344 likes and more than 2,139 comments.

This article examines how Nigerians use social media to interact with the state. It asks: How does social media facilitate conversations on what constitutes a national resource? How is social media creating citizens who are simultaneously anonymous and visible? It suggests that Facebook and other sites on which Jonathan established online presences were constructed as political spaces to interact with the youth of Nigeria, molding that constituency into loyal social media citizens ready to align with his aspirations. It also describes social media as sites on which the politics of claim-making produce the social mediation of oil as a commonwealth in Nigeria. The use of the term "social media citizens" is anchored in the fluidity of citizenship. Jonathan's use of Facebook as both public and political spaces elevated the site to a national forum on a resource whose distribution must benefit all Nigerians: oil. The article suggests further that social media can serve as a site on

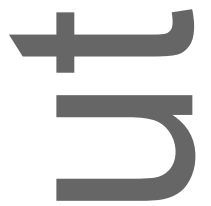

This is the alt manuscript accepted for publication and has undergone full peer review but has not been the th copyediting, typesetting, pagination and proofreading process, which may lead to differences betm this version and the Version of Record. Please cite this article as doi: 10.1111/plar.12217.

This article is protected by copyright. All rights reserved. 
which social media citizens can critique how the state manages and distributes oil.

[Facebook, oil, citizenship, soccer, state, governance]

(1)

In May 2010, Nigerian President Goodluck Ebele Jonathan made a speech in which he promised to set up a Facebook page:

I amhappy that the discourse and demand for free and fair elections are a nationwide current that cannot be stopped. Once again, I commit myself to working with all Nigerians, especially the youths to bring the sad days of electoral malfeasance to an end. As part of my contribution to this debate I will set up a Facebook account that will focus primarily on the exchange of ideas. (Ogbu 2010)

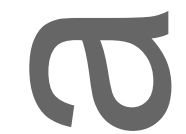

Then, on June 28,2010, Jonathan announced that he had set up his Facebook page. His post stated, inter alia:

Today, in fulfillment of the promise I made at the 26th convocation of the University of Port Harcourt on Saturday, 15 May 2010, I have created a Facebook fan page to interact with Nigerians. As I said on that day, there is an unchallengeable power of good in the Nigerian nation and her youth and through this medium I want Nigerians to give me the privilege of relating with them without the trappings of office. ${ }^{1}$

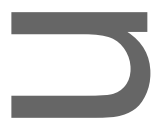

Jonathan, a minority of Ijaw heritage from the Niger Delta region, was the first person from a minority ethnic group to be elected president in Nigeria, a nation that is ethnically diverse but also rife with ethnic conflict. President Umar Musa Yar'dua was elected in in 2007 to a term of four years, but he died in 2010, after which then-Vice President Jonathan came into office. 
Considering the rancor that followed Jonathan's sudden elevation from vice president to president in a state deeply divided on ethnic lines, it is not surprising that Jonathan decided to make the support and mobilization of youths the focal point of his new presidency. By focusing on youth to become social media warriors, he envisaged support for his presidency from that critical segment of the Nigerian society. This focus on social media and youth culture was particularly important during the succession debate immediately after the death of Yar'dua.

\section{$\infty$}

Within a few days of announcing his Facebook page, Jonathan's first post garnered more than 1,340 likes and 2,135 comments. By October that year, he had "more Facebook fans than the combined tally of British Prime Minister David Cameron, German Chancellor Angela Merkel, and South African head of state Jacob Zuma." ${ }^{2}$ The likes and comments were an indication of potential interpersonal interactions between the president and his largest constituency: youths. In Nigeria, the category "youth" is very fluid, as people even aged up to mid-fifties might still refer to themselves as youths (Adunbi 2015). It was, therefore, not surprising for Jonathan to explicitly court those who categorized themselves as Internet-savvy youths. Many of those comments commended Jonathan for creating the page; soon thereafter, "friending" the president on Facebook became a source of pride for what I term the "social media citizens" of the nation-state of Nigeria.

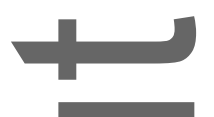

A few months into his presidency, however, that same Facebook page became a site for the condemnation of policies that many of these social media citizens considered inimical to the progress of Nigeria. This article addresses the shift from commendation to condemnation within the social mediation of politics in Nigeria. Building on the increasing research on the interface of social media with politics (see, e.g., Bernal 2006; Gerbaudo 2012, Howard et al. 
2011; Pype 2016; Shirky 2011; Turner 2008), I examine how Nigerians use the Facebook platform in unique ways to navigate the boundaries between those with political power and those without. I further demonstrate how these citizens of the oil-rich nation of Nigeria use social media not only to assert their ownership of natural resources such as oil but also to mediate political belonging in Nigeria. More importantly, I show how Facebook and other social media platforms serve as political spaces for citizens (e.g., Bernal 2006; Fattal 2012; Pype 2016; Soysal 2012; Stein 2012; Turner 2008), giving them outlets to interrogate the state's policy pronouncements, construct political alliances, and structure new social and political relationships. Therefore, I ask: How are Nigerians using social media to discuss issues with the state, ranging from the popular (e.g., soccer) to the more serious and controversial (e.g. oil and natural resources)? How is social media facilitating conversations on who owns national resources, and how are those conversations socially mediated? A form of visible concealment, I argue, shapes communication with the state- that is, citizens' views are visible via their posts on social media networking sites - but their identities can remain anonymous. Anonymity can be achieved both by using pseudonyms and by the ability to make these claims from the comfort and privacy of their smartphones, as opposed to speaking aloud in a public forum. This article is divided into four sections.

The first section is the methodology used to collect the social media data. The next section explores the circumstances that led to the emergence of Jonathan as the president of Nigeria. The circumstances of his emergence, I argue, helped shape the production of "the Facebook president" and the construction of social media citizens. In the following section, I interrogate the aftermath of various interactions that accompanied setting up a Facebook page by the president. This section particularly focuses on the president's intentionality of using Facebook as a site for the construction and production of loyal "friends." The section after 
that includes a discussion of poverty, soccer, and other aspects of the common Nigerian experience, which is intended to portray the president as "one of the people." The final section examines how social media citizens interacted with the discourse on oil in the public sphere. The section asks: How is it that social media sites, particularly Facebook, have become battlegrounds for contestations over ownership of oil resources in Nigeria? It also focuses on social media and ownership claims over oil resources by examining how Facebook has become a space for questioning certain state oil policies that are considered inimical to the interest of Nigerian social media citizens as well as Nigerians in general. I argue that this mode of questioning is anchored on the claim that oil resources do not belong to the state; rather, oil is seen as a commonwealth that must be used for the good of social media citizens and the entire country.

\section{Methodology}

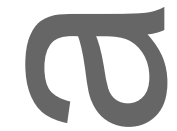

The data for this research was collected from three sources. First, in fall 2012, I set up Facebook and a Twitter accounts, both with the name GoverningNaijaOil. These accounts collect articles and opinions on oil and other governance issues; there are more than four hundred "friends" and "followers," most of whom claim to be Nigerians or interested in Nigeria. Second, between fall 2012 and summer 2015, three research assistants and I monitored the daily conversations on Jonathan's Facebook page. The comments and conversations from his Facebook page and GoverningNaijaOil page were extracted, processed, and analyzed. Third, popular Internet destinations for many Nigerians, such as saharareporters.com, Nairaland.com, Nigeriavillagesquare.com, and Nigeriaworld.com, were diligently followed during this period, and comments and conversations were extracted for analysis. It should be noted that this methodology, like any ethnographic method, carries several limitations. Most notably, Internet-published posts and comments lack the personal 
verification, background information, and other context cues available through traditional participant observation. However, the data collected over this three-year period provide a lens through which to gauge the ways in which many Nigerians who use social media engage with the state. For example, when we found that the president has common friends with GoverningNaijaOil, in some cases I was able to follow up with questions seeking clarifications on comments and conversations. Thus, what follows is the outcome of more than three years of using Facebook to observe interactions about spaces of politics in Nigeria. $\mathcal{C}$

\section{The Accidental President: Reconfiguring the Space of the State and Social Media}

On May 5, 2010, President Umaru Musa Yar'adua died after a long battle with what was said to be kidney disease and a heart problem. ${ }^{3}$ Though he was in and out of the hospital for most of his presidency, no official statement came from Aso Rock, Nigeria's seat of power, indicating he was ill. Some Nigerians in the diaspora, however, managed to set up sections in blogs, such as on saharareporters.com, from which they published details of the president's illness. For example, in a report dated November 22, 2009, saharareporters.com detailed Yar'adua's illness and suggested that he was going to be flown to Saudi Arabia that night. ${ }^{4}$ The president was indeed flown to a hospital in Jeddah and did not return to Nigeria until February 2010. At that time, there was also a widespread belief that Yar'adua's own kitchen cabinet — a group of a few of his loyalists that included his wife, Mrs. Yar'adua — was exercising control over state affairs, not Vice President Jonathan, as required by the constitution. The secrecy surrounding the president's illness, combined with this rumor, almost plunged the Nigerian state into a constitutional crisis. ${ }^{5}$ This perceived emergency led to the formation of the Save Nigeria Group (SNG), an organization led by a Pentecostal pastor, Tunde Bakare, who campaigned for the restoration of Nigeria to what he called "constitutional order." 
SNG members were seasoned political activists who had participated in the campaign, between 1983 and 1999, for the termination of military rule in Nigeria. They put their experience to use heralding a campaign to install Jonathan as acting president in Yar'adua's absence. In one of its first public statements in January 2010, the group stated:

The uncertainty in Nigeria has reached unprecedented levels and has led to demonstrations all over Nigeria and calls by pre-eminent Nigerian statesmen, including three former heads of state, and the International Community for President Yar'adua to obey the constitution and transfer power to his deputy until such a time as he is able to return to his duties ... We have received with relief and commend the resolution of the Senate of the Federal Republic of Nigeria calling on President Yar'adua to hand over power to his deputy as prescribed by the constitution, though we believe they could have acted much earlier and farther than they have gone. ${ }^{6}$

The campaign to make Jonathan acting president was extremely rigorous on social media. The SNG set up a Facebook fan page on which interested Nigerians could post comments identifying with the group's campaign. Other online spaces, such as the websites mentioned earlier, also set up various discussion forums for more intense debates. Significantly, many of the participants in these debates were young Nigerians who had only recently gained access to the Internet through the exponential rise in smartphone usage in the country (Kay and Spillane 2013). Through these debates, young Nigerians discovered the potential of social media to be used as a tool for campaigning on political issues; in this case, the restoration of constitutional order. Many Nigerians, particularly activist groups, fervently argued on social media that Jonathan be recognized as president based on the stipulation of the 1999 
Constitution, which states that in the absence of the president, the vice president must be sworn in as the substantive president of the Federal Republic of Nigeria. ${ }^{7}$ In February 2010, Nigerians" campaign for constitutional order was rewarded: Jonathan was installed as the acting president and, upon the demise of Yar'adua a few weeks later, Jonathan became the youngest and most educated president of the Federal Republic of Nigeria. His subsequent victory in the 2011 presidential election transformed him from an accidental president into an elected president, whose youthfulness and education endeared him to many young Nigerians. As noted above, this youthfulness was shown in his launching and active use of Facebook as a form of engagement with the Nigerian public (Adunbi 2011).

\section{Engaging the Facebook President}

Jonathan's Facebook page allowed him to tap into his political capital - the vast support he had from Nigerians, especially youths — - while the uproar over who would succeed Yar'adua was going on. A product of the ruling elite, Jonathan reimagined himself as a champion of the youths with an unparalleled presence on social media. In doing so, Jonathan facilitated regular interaction with these youths, who are considered to be the majority of the population in Nigeria and an important constituency (Sommers 2011). The CIA World Factbook suggests that of the estimated 180 million population of Nigeria, 62.4 percent are in the age range of $0-24$ years, 30 percent are in the range of 25-55 years, and 3 percent are 65 and older. ${ }^{9}$ Internet usage is largely dominated by the youths in Nigeria. The country has one of the fastest growing Internet usages in the world, moving from 200,000 Internet users in the year 2000, to more than 97 million users by the end of June $2015 .{ }^{10}$ Jonathan hoped to cultivate this significant population and harness them for political reasons; his creation and use of the Facebook page thus enabled him to mimic the rise of Internet use in young Nigerians and portray himself as one of them. 
One indication of Jonathan's "belonging" to the youth category was the initial comments ( posted by his Facebook fan page shortly after it was activated. Most of the posts, especially in the first few days, tended to consist of brief, welcoming, and congratulatory messages. Users seemed to want to show their approval of his decision to join Facebook ("Well done your excellency!!!" or "Congratulations! Thank you Mr. President," or "Welcome to FB Mr. President!"). Most expressed appreciation for what they saw as Jonathan opening a "direct" line of communication, hailing the move as unprecedented, democratic, and modern. In fact, a number of users compared him to U.S. President Obama, and took this move as proof that the president and Nigeria were entering a new, more up-to-date era. Many users commented that this would help get the youth involved in governance, and many young users welcomed or thanked Jonathan for joining “on behalf” of the youth. These comments were largely directed at the president himself, rarely acknowledging or responding to other users' comments. As time passed, longer messages appeared, some a few paragraphs long, detailing what each user thought was the most important issue for the president to work on. Some invited the president to contact them for individual discussions, publicly leaving their e-mails, phone numbers, or even home addresses. Through constant interaction with the president on social media, many participants were transformed into social media citizens.

My use of the term "social media citizens" is anchored in the fluidity of citizenship. To understand the connections among social media, citizenship, and ownership of national resources, I first examine how the concept of citizenship has shifted from being in the purview of the state to being a cultural construct. Many argue that citizenship is no longer a prerequisite for state membership (see, e.g., Clarke 2004, 2013; Hindess 2002, 2004, 2005). Contemporary literature on citizenship critically interrogates the shift in citizenship discourse 
from being a derivative of state regulatory bodies to being a flexible category in the age of transnational emigration patterns (see, e.g., Clarke 2004, 2007, 2013; Hindess 2002, 2004, 2005; Ong 1996, 1999; Rosaldo 1994, 2003). Ong (1999, 6), for example, calls this flexible citizenship, a form of citizenship that is at the intersection of "cultural logics of capitalist accumulation, travel, and displacement that induce subjects to respond fluidly and opportunistically to changing political-economic conditions.” These conditions result in certain migratory practices that prioritize the acquisition of different citizenships. For example, acquisition of nation-state citizenship is considered to be more beneficial than transnational citizenship in competitive global economic practices because of the privileges attached to it - privileges such as the use of travel documents issued by the nation-state. Hindess $(2002,242)$ invites a critical thinking of the shift from state citizenship based on civil, political, and social rights to a much more transformative citizenship that encompasses "a supranational governmental regime in which the system of states, international agencies and multinational corporations all play a fundamental role."

While Ong and Hindess problematize citizenship practices that are anchored on changing global economic and political climate, Clarke $(2004,2012)$ suggests that cultural practices and citizenship are interwoven and interconnected. To Clarke (2004, 2007, 2013), citizenship is no longer an exclusive purview of the state; the logics of cultural practices also suggest that cultural citizenship is becoming more and more de-territorialized. She urges distinguishing between "a more formalistic notion of citizenship that is managed by the state and a more cultural notion of citizenship that invokes a range of factors that span racial, ethnic, linguistic and geographical forms" (Clarke 2013, 467). In applying the same logic of changing practices around notions of citizenship, I propose that an engagement with the state by social media actors is a form of citizenship, in which proficiency in the art of social media 
networking becomes a marker of gaining membership in the realm of social mediation of discourses about the state. The language of social media - the ability to write while minimizing the use of words, to convey a set of meanings that can be decoded by other practitioners of social media-becomes one of the major signifiers of citizenship in the social media world. Some examples of these forms of citizenship claims can be seen in the comments (highlighted above) that welcomed President Jonathan to Facebook when he launched his page in 2010. While some of the comments attempted to introduce Jonathan to acceptable ways of gaining membership by mastering social media language, others scolded those users who posted lengthy comments, accusing them of being too grammatical and saying that such comments are meant for academic and not social media platforms. These displays of "public intimacy" (Soysal 2010, 375)—that is, "shared, discursive, and performative spaces of public engagement - rather than the private spaces of the cultural kind" structure such spaces. Within them, "networked publics" (Boyd 2010; Boyd and Ellison 2007) are formed, in which issues of state policy directions are discussed and negotiated in the networked public sphere (Baym and Boyd 2012; Habermas 1991, 2006;

Shklovski and Valtysson 2012). Immersion in issues of state policies through social media interactions helped cement the notion of belonging into a particular networked public sphere - the social media space — where Nigerians who traverse these spaces consider themselves "experts" of the social platform and "owners" of the spatial mediation of politics.

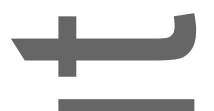

Many of the messages of welcome aimed at Jonathan, interestingly, show that the Nigerian users felt a kind of ownership of this networked public web space. They saw themselves as the "experts"- - longtime residents of the Facebook forum that the president was now entering. In a sense, the president was not only "coming down to [citizens'] level" 11 but also entering a realm where "the people" saw themselves as more knowledgeable than the 
president. This teaching or authoritative attitude was seen in some comments, such as the person who explained Facebook's abbreviation: "Welcome Mr. President to FB (Facebook)."12 Others warned the president of the potential pitfalls of this web space. For example, someone cautioned, "One advice Mr President, facebook is addictive." ${ }^{13}$ Some also warned about trolls or the potential lack of Facebook etiquette: "Some may be rude but pls ignore and work right." ${ }^{\prime 14}$ What these various comments show is perhaps an unconscious role reversal, in which the "ordinary citizens" were better placed to lead the president.

\section{$\mathcal{C}$}

Some comments expressed a certain amount of skepticism, arguing that the president would not have the time to read and respond to all of the comments. The users did not seem to doubt his willingness to do so; rather, they seemed to doubt that he understood just how much time Facebook can take; hence, the proposition that it can be addictive. A few users also expressed doubt that the president himself was really the person posting and responding. The true identity of whoever posted on the behalf of the president seemed unimportant to many of the people that I interacted with on Facebook; nevertheless, it is important to note that Jonathan did hire a special assistant of New Media to set up his various social media platforms. The assistant, Reno Omokri, was a political consultant who had worked as the vice president for Africa, Joe Trippi and Associates, a political consulting group in the United States, before making a transition to work for the president of Nigeria. To many commenters, having such a special assistant was an acknowledgement of the importance Jonathan attached to social media and the value of those who participate in crafting conversations on the platform. While it may be assumed that Facebook is a democratic and effective way for politicians to communicate with ordinary citizens, some users also critiqued this idea. They pointed out that Facebook is not a space of equal access: "Mr. President, how I wish every Nigerians can join you on facebook by you making sure there is $24 \mathrm{hrs}$, 7 days a week electricity. I don't 
think you should be facebooking or using Internet when other noble Nigerians doesn't have electricity to keep the refrigerator in their house working." 15 This particular comment was, of course, in reaction to the challenges of electricity distribution in the country.

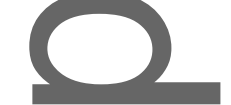

The rhetorical practices of the comments were quite varied. Some users employed formal language and standard grammar, as one would expect to see in a letter or article. Other messages seemed quickly and carelessly composed, with typos and fragmented sentences. Others ignored the conventions of punctuation and capitalization altogether, relying on the abbreviations common in Internet language usage. Nonstandard written English has become the norm throughout global social media, but what makes the Nigerian example more interesting is the incorporation of Nigerian Pidgin English into the nonstandard written English as a medum of communication. This democratizes its usage and creates its own unifying convention that sets Nigerian users apart. More importantly, it enables access in ways that allow those who are not highly educated to participate in national debates. With a 51.08 percent literacy rate, according to the United Nations Educational Scientific and Cultural Organization, Office of Statistics Estimate, it is clear why Pidgin English remains the most accessible language that cuts across ethnic language barriers: every one speaks it in addition to their local dialects. ${ }^{16}$ For example, after one user posted a lengthy and elaborately composed comment, a few others responded by berating him for his rhetorical choices. One user wrote:

@ Mubarak ... I beg ur pardon! ... this is not a platform to flex ur grammatical/vocabulary prowlness.... u dont need too much grammar to relate with the president... why you come dey write big big grammar? just simple communication is wat we require ... the man will be too bored reading ur theatric essay ... pls dont abuse his page $\ldots$ ok. ${ }^{17}$ 
The president's posts, in general, consisted of commentaries on social, economic, and political matters. Sometimes, to show individual engagement, his posts included names of citizens who had commented on previous posts. He was just as likely to comment on the television show Big Brother Africa, which Uti Nwachukwu, a Nigerian, won in 2010, as he was to mention his inclusion in Time magazine's list of the100 most influential people in the world. When addressing the public, he often used phrases such as "we must" or "we should." Jonathan's use of "we" was meant to indicate the collective nature of what he was proposing: both the state and citizens had roles to play, and "we are in this together." 18 To further encourage the idea that the state and citizens needed to work together, Jonathan often asked for feedback on current issues. For example, he wrote: "I need your feedback. Has the power situation in your area improved, remained the same or deteriorated? Please let me know so I can take your views into consideration in making policy decisions. GEJ." ${ }^{19}$ While signing posts with initials is generally outside the Facebook convention, Jonathan used this signature to emphasize his personal involvement with the post, distinguishing it from an official staff announceme

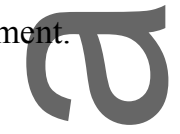

After receiving feedback, Jonathan sometimes wrote that he had read everyone's comments and made a presidential directive to the appropriate government official. In such posts, it was clear that the president wanted to interact with, not just speak to, his followers. This interaction continued in Jonathan's posts on policy issues. Here, he usually talked about an action he had taken, the state's position on a policy issue, or that he was contemplating an action based on things said on Facebook. Such posts were primarily official speeches or statements on keypolicy matters (archived under "Notes" on his Facebook page).

Of course, Jonathan also used his page to respond to criticism. He sometimes made a direct reference to a publication or news reports in the national newspapers, such as he did in a post that he titled, "I was grossly misunderstood." In it, he berated those who "twist words beyond intended meaning" in ways that are "unhelpful to public discourse." ${ }^{, 20}$ Other times, it was 
unclear where the critique he was responding to had come from. Finally, the president used Facebook for general greetings, such as holidays, birthday messages, and commemorative occasions, and as proof that he was fulfilling his duties; these included, for example, updates on presidential activities, evidence of his appearance at state functions, and other events. All of these varying types of posts reflect the different ways that Jonathan tried to engage with citizens on Facebook.

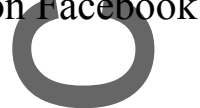

As Baym and Boyd $(2012,327)$ note, "national and cultural modes of understanding" are key to deciphering interactions between the state and citizens. Following this logic, I suggest that Jonathan's online presence demonstrated that such interactions between the state (Jonathan) and its citizens (his Facebook friends and Twitter followers) legitimized his attempts to promote cultural and national modes of understanding and to cultivate citizens to support state policies. Facebook, Twitter, and other sites on which Jonathan, as president, had an online presence were, thus, constructed political spaces in which he interacted with the youth of Nigeria and molded that constituency into a loyal army of social media citizens, ready to align with his aspirations as a politician. In the next sections, I show that this motivation invariably conflicted with the expectations of some segments of this constituency. While having an imagined audience is fundamental to human communication - that is, people selfpresent based on some imagination of whom they will communicate with (Goffman 1959) "social media makes it particularly challenging to understand 'who is out there and when' and raises the potential for greater misalignment between imagined and actual audiences" (Baym and Boyd 2012, 323). The reimagining of Nigeria's political landscape as a space for the production of new imaginaries, dictated by socially mediated communication, became crystal clear when Jonathan used Facebook to announce his campaign to run for a new full four-year term in $2010 .^{21}$ 


\section{Social Media, Soccer, and the "People's" President}

In his long write up reintroducing himself to Nigerians as a candidate of the Peoples

Democratic Party (PDP), the ruling party, Jonathan placed special emphasis on his poor

background. He came from an impoverished home, just like many Nigerian youths. On

Facebook, he wrote:

Not once did I imagine that a child from Otuoke, a small village in the Niger

Delta, will one day rise to the position of President of the Federal Republic of

Nigeria. I was raised by my mother and father with just enough money to meet our daily needs. ... I carried my books in my hands but never despaired; no car

to take me to school but I never despaired. There were days I had only one meal but Inever despaired. ... Didn't have power, didn't have generators, studied with lanterns but I never despaired. In spite of these, I finished secondary school, attended the University of Port Harcourt, and now hold a doctorate degree. Fellow Nigerians, if I could make it, you too can make it! My story is the story of a young Nigerian whose access to education opened up vast opportunities that enabled me to attain my present position. ${ }^{22}$

Many "liked" the post, and several commended him for all his perceived achievements. More importantly, many of the youths could relate to his "I had no shoes" story, considering Nigeria's substantial and ongoing socio-economic problems (Adunbi 2015; Apter 2005; Ferguson 2002, Smith 2007). After the president published this post about his poor background, the fulcrum of many of his subsequent posts centered on youth and used the word "our" to build rapport with the people. These two important words — "youth" and “our" - framed Jonathan as a leader and a "people's president" dedicated to reconfiguring the 
state in transformative ways. This promised transformation placed the largest and most important population of the state - the youths — at the center of policy pronouncements, even if those pronouncements were not carried out.

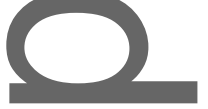

Besides his poor upbringing, Jonathan connected to the people by merging his appeals to both national identity and transnational citizenship through engagement with a particular public sphere: social media. As Habermas (1991) suggests, the public sphere performs essential political functions within a society; in this case, the public sphere in question occurred through social media. Citizens connected their national identity (as citizens of Nigeria) to their membership of a de-territorialized social media world. The comments welcoming the president to the world of Facebook demonstrated both types of performed identities: the local (nation-state citizenship) and the global (membership of a global social media). Affordances aside, "national and cultural modes of understanding" (327) are also crucial to understanding what shapes interactions between people on social networking sites. For example, the president's use of soccer as a touchstone topic to reach the youth was an indication of his knowledge of the "likes" and "dislikes," to use Facebook terms, of the group he was trying to cultivate. The state presented state policies to social media citizens through the networked public via social media, and members of the networked public responded to such policies by engaging with the state through comments that were sometimes imbued with vituperation.

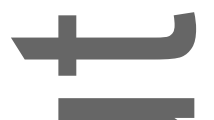

In cultivating this important segment of society, Jonathan constantly shifted from policy pronouncements to everyday and popular culture issues, such as posting his inclusion in Time magazine's 100 most influential leaders or sharing his thoughts on soccer. Soccer is considered the national pastime of Nigeria, and many youths either follow their favorite soccer team's exploits or simply follow the national team of Nigeria. Posts related to soccer 
sometimes drew on national pride and the resilience of Nigerian teams when representing the Nigerian state at international competitions. For example, in one such post, Jonathan discussed a memory from his childhood to highlight what he saw as a strong example of the youths' resilience and doggedness:

We-must be hopeful about the future. Our history has shown that Nigerians hayera strong can-do-attitude and are capable of winning even in the face of very difficult circumstances. ... Some of you may recall the 1989 "Miracle of Damman" in Saudi Arabia when our Flying eagles unbelievably came back from being 4-0 down against the USSR to equalising and eventually winning the game!... You helped to bring about this democracy and when I say that Nigerian youths have in them the stuff that greatness is made of, I know this to be true. I will work with you to realise our potential as a great Nation. GEJ."23

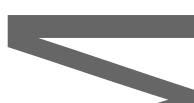

The constant shift from issues of policy to popular culture provided an avenue for Jonathan to present himself as a president who connected with the everyday lived experiences of all Nigerians, especially the youths. The popularity of soccer among youths is too substantial to be measured and provides a sense of hope throughout the country. A good example is Jonathan's response to what many considered to be a disastrous outing by the Nigerian national soceer team, the Super Eagles, at the 2010 FIFA World Cup. ${ }^{24}$ Many Nigerians had Then expected their national team to do well because the soccer competition was taking place on the African continent, but the Super Eagles were eliminated in the first round without winning a single match. This loss prompted President Jonathan to dissolve the Nigeria Football Federation, the soccer governing body affiliated with FIFA. Predictably, FIFA saw Jonathan's decision as state interference in soccer affairs and, in response, placed a ban on 
Nigeria. ${ }^{25}$ FIFA's ban, also unsurprisingly, was not well accepted by many Nigerians, and they transferred their anger to Jonathan, accusing him of insensitivity to the aspirations of many Nigerians. Several comments on the president's page heavily criticized him for taking an action that incurred the wrath of FIFA. In response, a few days later, Jonathan rescinded his decision, and FIFA lifted the ban on Nigeria. In his Facebook post, Jonathan wrote:

Dear friends, I read your comments and took them into account in the goyernment's decision to rescind the suspension of Nigeria from International Football.... To Suleiman [last name], Nwanze [last name] and Ifade [last name] and the hundreds of Nigerians who appealed to me on this page, I have listened to your voices and those of others and we must now work together to make sure that the NFF and our players do us proud in future events. GEJ. ${ }^{26}$ (

By mentioning the names of a few of those who commented on his Facebook post, Jonathan personalized his political decision and appealed to the sense of personal connection associated with social media spaces. Jonathan was able to make the connection by showing that he notonly watched the World Cup, in which Nigeria performed below expectations, but also that he identified with the aspirations of many Nigerian youths who wish their national team well. Three names mentioned in his post, Suleiman, Nwanze, and Ifade—names associated with the three main ethnic groups (Hausa/Fulani, Igbo, and Yoruba, respectively) — also demonstrated that Jonathan wanted to be seen as a president who could connect with allNigerians, whatever their ethnic or religious backgrounds might be.

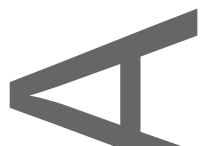

Jonathan engaged and interacted with youths on many facets of Nigeria life, and these exchanges could be be fierce depending on the political, cultural, or policy issue on which the 
interaction was anchored. A good example of the fierceness of these interactions between Jonathan and Nigerians on Facebook and other social media platforms is observable through the lens of oil: a valuable and contentious commodity considered to be a commonwealth by many Nigerians. As I point out in the next section, a policy pronouncement and its implementation on oil was to later shift the attention of Nigerians from commending Jonathan tocondemning him as president. This shift marked an important transformation in Jonathan's interaction with social media citizens.

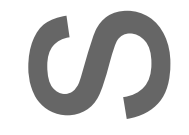

\section{Social Media Citizens and the Commonwealth Called Oil}

The romance between Jonathan and his target constituency-youths_-did not last long. Many of those who had commended him when he first assumed office as president later became his ardent critics, using his Facebook page as a platform to object to his continuation in office. An example of this change is seen in the responses to the president's attempt to use Facebook to position the Nigerian state as an important member of the comity of nations, such as when he cited his ability to bring foreign direct investment to Nigeria, evidenced by his ringing of the New York Stock Exchange's closing bell on September 23, 2013:

Today, Thad the honour of ringing the closing bell at the New York Stock Exchange after I had heralded to global captains of industry Nigeria's efforts in recent times that has made our nation a prime destination for foreign investment and one that ensures some of the highest Return on Investments (RoI) in the world. This is just the beginning of greater things to come for our country and our continent. The foundation of planning which we laid at the inception of our administration is being strengthened for greater service delivery for our people. GEJ. ${ }^{27}$ 
This claim, however, was not enough to dissuade social media citizens from seeing his administration as a failure. The shift in tone from celebratory to condemnation, I argue, is anchored on the notion of natural resources, in this case oil, as a commonwealth owned by the Nigerian citizens but perceived to be mismanaged by the Nigerian state. More than 95 percent of Nigeria's annual revenue comes from oil and, because revenue is centralized, all of the money goes to the central government (Adunbi 2015; Apter 2005). As a result, it is the central government, not the citizens, that decides how the revenue from oil will be spent. Many of the comments that followed the NYSE closing bell post mimic several other comments monitored over a period of three years - 2011 to 2014 - all of which made it clear that citizens felt that Jonathan's spending of the oil revenue was wasteful. Such comments, and their stbsequent responses, beg the following questions: How did the notion of oil as a commonwealth emerge? Why did citizens assume all Nigerians owned oil, situated in the Niger Delta? How did social media citizens contest the Nigerian state's management of the perceived commonwealth? In this last section, I describe social media space as a site in which the politics of claim-making produced what I call the social mediation of oil as a commonwealth in Nigeria. There is significant literature on oil as an important national resource (e.g., Adunbi 2015; Apter 2005; Mitchell 2011; Ross 1999; Shever 2012; Sawyer 2004; Watts 2007, 2012). For many years, the debate on oil as a national resource has ranged from the commodity being a curse for states rich in such resources (Ross 1999), to its fueling insurgency in ways that create different claim-making processes within communities rich in this resource (Adunbi 2015; Watts 2007, 2012), to the materiality of oil and its capacity to limit democratic practices in places such as the Middle East (Mitchell 2011). As Rogers (2014) points out, oil is an important commodity to nation-states because of the ways in which the commodity shapes politics, for example as petrobarter for the Russian state. My interest is to look at other ways in which oil can generate a particular discourse that centers 
on social mediation of politics in a nation-state. The Nigerian state presents a good example of how oil (and its properties) served as a commodity that generated social media interest among Nigerians. Thus, oil created spaces in which social media citizens who belonged to a particular networked public sphere engaged in the discourses of the use of oil as a commonwealth.

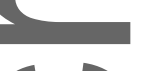

The idea of oil as a commonwealth was shaped by social media citizens, who constantly engaged with the president through his Facebook page regarding the distribution of oil rents in Nigeria. The president's ability to use Facebook as both public and political spaces elevated the site to a national forum for promoting the idea of a national resource as a commonwealth, whose distribution must benefit not only social media citizens but also all Nigerians. Moreover, the networked public created from oil-related discussions on social media conferred on itself the authenticity of representing the entire nation of Nigeria, especially disenfranchised Nigerians. This form of representation was embedded in comments that deployed words such as "our oil" to denote oil as a commonwealth of all Nigerians. However, oil is legally considered a state property by virtue of the Petroleum Act of 1969 and the Land Use Act of 1978 (Adunbi 2015; Apter 2005).

Contestation of the state's power over oil emerged with Jonathan's decision to withdraw the subsidy on local oil consumption, which he announced on January 7, 2012. A few days before the announcement, the Nigerian state rolled out a program to deregulate the downstream sector of the oil industry, in which the government withdrew the petroleum subsidy. This deregulation translated to an increase in the prices of petroleum products such as Premium Motor Spirit (PMS) and kerosene, which most Nigerians use for cooking. With an increase in gas costs, the price of many staple foods also rose because farmers and market 
workers depend on PMS for the daily transportation of agricultural produce to the market. Social media citizens met this sudden withdrawal of subsidies on petroleum products with condemnation. The attacks were mainly directed at the president's announcement on Facebook that implored all Nigerians to bear with him because he was "making the right choice for a better tomorrow." 28 The condemnation of the president's act was further amplified because many Nigerians, particularly those who live in cities such as Lagos, Ibadan, and Abuja, travel over the long Christmas and the New Year holiday to celebrate with their loved ones in villages and towns. Many Nigerians consider this time as an opportunity to reunite with their families and relatives. The president wrote:

This evening, I address you, again, with much concern over an issue that borders on the national economy, the oil industry and national progress. As part of our efforts to transform the economy and guarantee prosperity for all Nigerians, Government, a few days ago, announced further deregulation of the downstream petroleum sector. The immediate effect of this has been the removal of the subsidy on petrol. ... Since the announcement, there have been mixed reactions to the policy. Let me seize this opportunity to assure all Nigerians that I feel the pain that you all feel. I personally feel pained to see the sharp increase in transport fares and the prices of goods and services. I share the anguish of all persons who had travelled out of their stations, who had to pay more on the return leg of their journeys. ${ }^{29}$

Even though Jonathan explained his actions by saying that he was trying to minimize the pain to Nigerians, many social media citizens saw through this claim that citizens would suffer only temporarily as a result of the deregulation. Many questioned the rationale for taking this 
action because, as mentioned above, they believed oil to be a commonwealth of all Nigerians, and it should bring happiness, not pain, to citizens. Jonathan's Facebook post generated more than 16,000 comments, many of which were on how the oil should be used for the benefit of all Nigerians. For Jonathan, deregulating the downstream sector of the economy constituted using the oil to benefit everyone. To many social media citizens, however, the removal of oil subsidies meant Nigerians were denied the benefits of oil. Some of the comments argued that it was not just deregulation but also a conspiracy by Western nations that want to use "our oil money to rebuild their economy." ${ }^{30}$ Here, the person who wrote this post was referring to the domination of the oil industry by multinational corporations such as Shell, Chevron, ExxonMobil, TotalFinaElf, and Agip, all headquartered in the West (Apter 2005; Adunbi 2015; Shever 2102). This person urged Jonathan to tell Finance Minister Ngozi Okonjo Iweala, who had announced her intention to run for president of the World Bank before the deregulation announcement, not to use "our [Nigerians] oil money" to help Western nations and "to prepare herself for the world bank presidency because she will never be." While this post suggests the existence of a Western conspiracy against Nigeria and Jonathan, other commenters suggested that Jonathan was merely sacrificing the happiness of Nigeria to satisfy the interest of the "cabals" that controlled the oil sector. ${ }^{31}$ To the person who wrote this post, these cabals encompassed the oil corporations and their Nigerian collaborators who "want to take our oil from us," and he argued that the price of oil would not come down until the "internationalmarket price falls to $\$ 50$ per barrel or our refineries work to full capacity." He continued:

The said temporary pains is unrealistic since Mr President will not be able to control the Cabals in the oil sector. They will continue to make excess profit on Nigerians. GEJ just have to return our subsidy until an alternative source as 
proposed work efficiently for Nigerians then, the demand for PMS may fall which will then force down the price of petrol. ${ }^{32}$

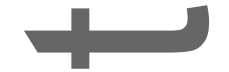

Another commenter believed that the president and his ruling party, the PDP, were colluding with said "oil cabals" to impoverish Nigerians by raising the price of the product. She also addressed the president personally:

Mr President, You and your PDP led govt can never be trusted again. Ur speech tonight makes no difference becos much more of dat have been promised and whre are we today? Why is govt not addressing the issue of our own refineries? Who are this cabal and why can't govt charge them for corruption? Mr President, do u know how it feels to be living on less than 1usd per day ? $70 \%$ of Nigerians are poor due to past and present govt corruption. Ur excos, ur governors and all those will see it as another avenue of getting more money to enrich themselve will only support $u$ on this ur untimely and wicked policy. Am divinely advising u Mr President, to reverse the subsidy back to 65 or resign honorably. ${ }^{33}$

While many of the commentators addressed the president from their point of view as loyal social media citizens who regularly used Facebook to communicate with him, others issued long lists of demands on behalf of those Nigerians not on Facebook or on other social media. For example, someone posted a list of demands that encapsulated this notion of acting on behalf of all Nigerians, and he suggested that he was not acting alone but rather represented those Nigerians without access to the Internet. He started his post by, once again, positing that oil was a national resource owned by all Nigerians, and that such national resources 
should not be used to compound the suffering that Nigerians have endured in periods of economic crisis:

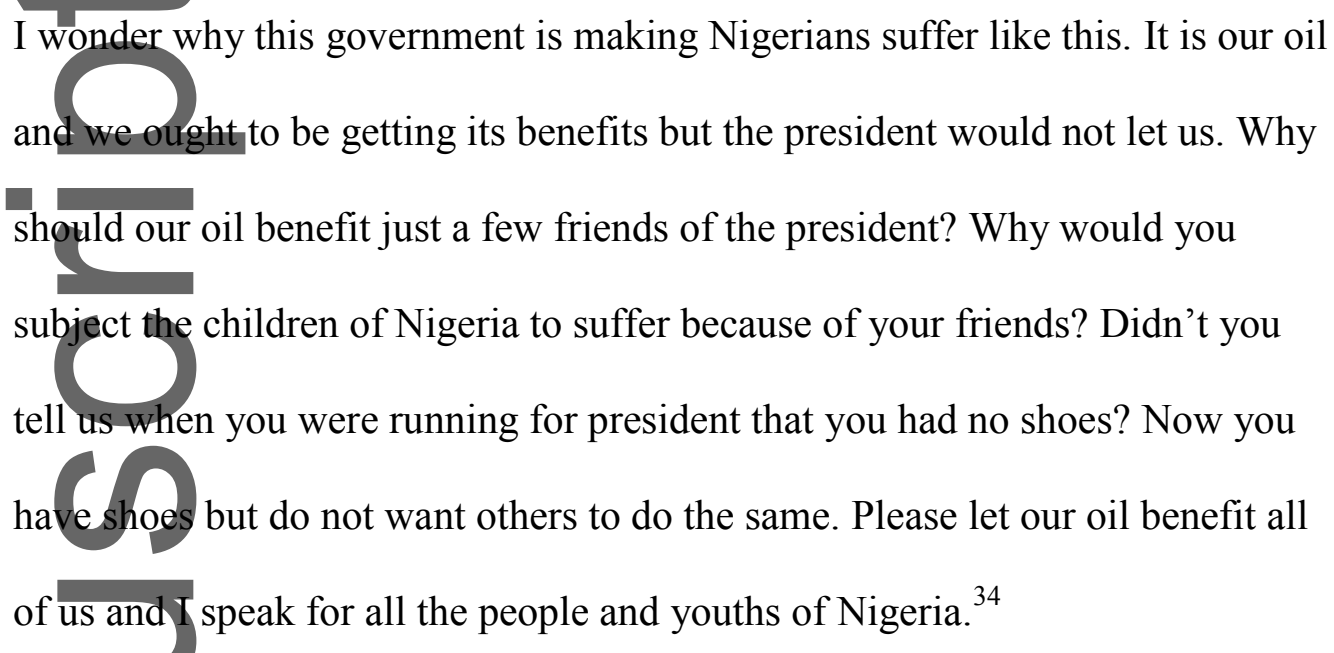

This post further suggested that oil, although a critical part of the economy of Nigeria, is at the same time a commonwealth that the state is only holding in trust for the populace and, as such, should not be subjected to the whims of economic indicators.

On March 28, 2015, only two and a half years after that post, Muhammadu Buhari, a retired military general and former military head of state from 1983 to 1985, defeated Jonathan in the next election. In the weeks leading up to the election, the social media space was abuzz with posts either supporting or opposing Jonathan's attempt to win a second term. Early on, Jonathan had succeeded in courting the youth through social media, but this same demographic was responsible for highlighting what they considered to be the president's indolence on oil money working for all Nigerians. Thus, the 2015 election proved the limitations of the president's social media approach: portraying himself as "one of the youths" did not qualify him to determine how Nigeria's national resource commonwealth should be shared among all people. 
Buhari's use of social media is very different in strategy and approach. While Jonathan presented himself as directly engaged with the Nigerian people, Buhari presents the opposite image. Buhari relies on third-party bloggers and activists to manage his social media accounts, including popular Nigerian bloggers and social media activists Japhet Omojuwa ${ }^{35}$ and Kayode Ogundamisi. ${ }^{36}$ Buhari's unofficial online support groups include the President Muhammadu Buhari Supporters Club On Facebook; ThisisBuhari, another Facebook page; @ThisisBuhari, a Twitter account; and "I am a Buharist," a Facebook group that has a membership of 60,468 with the sole objective "to promote Buharism and good governance. ${ }^{37}$ Buhari's strategy seems to be the promotion of a cult following based on his perceived integrity as an anti-corruption crusader in a nation reeling from corrupt practices (Smith 2007). Buhari appointed Tolu Ogunlesi as special assistant on Digital/New Media; he is a two-time winner of the CNN Multichoice African Journalism Award and is a 2015 New Media Fellow of the US State Department's International Visitor Leadership Program. ${ }^{38}$ Ahmad Bashir was appointed as special assistant on Social Media; he is the online editor of the Leadership Newspapers, one of the leading newspapers in Nigeria. ${ }^{39}$ Both Ogunlesi and Bashir are popular and trendy bloggers, both were ardent supporters of the Buhari for President project, and both were instrumental in shaping the debate on the failing presidency of the Jonathan administration through social media posts that criticized his handling of the economy and oil revenue. While trying to appeal directly to Nigeria's youth, Jonathan opened himself up to criticism that ultimately proved fatal to his administration. Buhari aims to avoid the mistakes of his predecessor by maintaining a strong online presence while also keeping a personal distance.

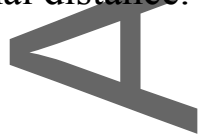

\section{Conclusion}


The evidence presented here demonstrates how political leaders and citizens can use different social media as sites of interaction that shape debates on national policies, popular culture, and the distribution of public goods. It also shows that while political leaders might use social media platforms as sites for cultivating political support, social media citizens can also take control of these platforms and use them to critique how the state manages and distributes national treasures, such as oil. In an attempt to galvanize support from those who use social media, particularly the youths of a nation-state, politicians can create their own spaces within social media for example, by joining Facebook and allowing all social-media savvy youth to "friend" them. This was exactly what President Goodluck Ebele Jonathan wanted when he created a Facebook page to discuss state policies, popular culture, and other topics of national interest with those who friended him.

\section{(U)}

Through Facebook, Jonathan sought to personalize his political decisions and take advantage of the informal personal interactions that take place within social media spaces. The president's entry into the world of Facebook, originally aimed at endearing him to youth culture, failed in the end to serve the purpose he had envisaged. In fact, his social media presence may have played an active role in his political demise, giving citizens a forum within which to speak their criticisms to a wide audience of Nigerians. What became clear in many of the posts was the fact that his popularity as a "Facebook president" had waned drastically. He was no longer the popular president who many social media citizens had welcomed into their world with warnings about how addictive Facebook could be. Many of those who fought for Jonathan to ascend to the presidency viewed his administration optimistically, hoping that he would enact policy changes that would ensure the equitable distribution of oil wealth. When that proved to be an uphill battle, Facebook also became a platform for the condemnation of many of Jonathan's policies. The shift in tone from 
celebratory to condemnatory, I argue, only emerged because of the ability of many Nigerian citizens to engage the state through Facebook, without fear of penalty for their political views. The "visible concealment" granted to social media citizens allows them to speak their minds in a public setting and spread their criticisms of the government throughout a wide audience, while remaining sheltered from political repercussions. Meanwhile, direct relationships can be cultivated between the rulers and the ruled. Social media thus represents a unique platform for political engagement, one that has been instrumental in shaping questions on the place of oil, popular culture, and belonging in Nigerian national politics.

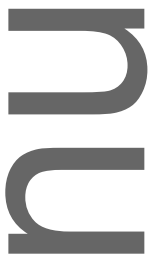

\section{NOTES}

\section{References Cited}

Adunbi, Omolade 2011. "Oil and the Production of Competing Subjectivities in Nigeria: 'Platforms of Possibilities' and "Pipelines of Conflict." African Studies Review 54 (3): 101 20. doi:10.1353/arw.2011.0064

2015. Oil Wealth and Insurgency in Nigeria. Bloomington: Indiana University Press.

Apter, Andrew. 2005. The Pan African Nation: Oil and the Spectacle of Culture in Nigeria. Chicago: University of Chicago Press.

Baym, Nancy K., and Danah Boyd. 2012. "Socially Mediated Publicness: An Introduction." Journal of Broadcasting \& Electronic Media 56 (3): 320-29.

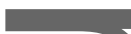

Bernal, Victoria. 2006. "Diaspora, Cyberspace and Political Imagination: The Eritrean Diaspora Online.: Global Networks 6 (2): 161-79. 
Boyd, Danah. 2010. "Social Networked Sites as Networked Publics: Affordances, Dynamics, and Implications." In A Networked Self: Identity, Community, and Culture on Social Network Sites, edited by Zizi Papacharissi, 39-58. New York: Routledge.

Boyd, Danah, and Nicole B. Ellison.2007. "Social Network Sites: Definition, History, and Scholarship." Journal of Computer-Mediated Communication 13(1): 210-30.

Clarke, Maxine K. 2004. Mapping Yorùbá Networks: Power and Agency in the Making of Transnational Communities. Durham, NC: Duke University Press. 2007. "Yoruba Aesthetics and the Making of Trans-Atlantic Imaginaries." In Beautiful Ugly: African and Diaspora Aesthetics, edited by Sarah Nuttall, 290-315. Durham, NC: Duke University Press. 2012. "Kony 2012, the ICC, and the Problem with the Peace-and-Justice Divide." ASIL Annual Meeting Proceedings 106: 309-13.

2013. "Notes on Cultural Citizenship in the Black Atlantic." Cultural Anthropology $28(3): 464-74$.

Fattal, Alex. 2012. "Social Buzz, Political Boom? Ethnographic Engagements with Digital Militancy." Anthropological Quarterly 85 (3): 885-891.

Ferguson, James, 2002. "Of Mimicry and Membership: Africans and the "New World Society.". Cultural Anthropology 17 (4): 551-69.

Gerbaudo, Paolo. 2012. Tweets and the Streets: Social Media and Contemporary Activism. London: Pluto Press.

Goffman, Erving, 1959. The Presentation of Self in Everyday Life. New York: Doubleday. Habermas, Jürgen. 1991. The Structural Transformation of the Public Sphere: An Inquiry into a Category of Bourgeois Society. Cambridge, MA: MIT Press. 
2006. "Political Communication in Media Society: Does Democracy Still Enjoy an Epistemic Dimension? The Impact of Normative Theory on Empirical Research.” Communication Theory 16 (4): 411-26.

Hindess, Barry. 2002. "Neo-liberal Citizenship.” Citizenship Studies 6 (2): 127-43.

(10)

2004. "Citizenship for All.” Citizenship Studies 8 (3): 305-15.

2005. “Citizenship and Empire." In Sovereign Bodies: Citizens, Migrants, and States

in The Postcolonial World, edited by Thomas Blom Hansen and Finn Stepputat, 24156. Princeton, NJ: Princeton University Press.

Howard, Philip N., Aiden Duffy, Deen Freelon, Muzammil Hussain, Will Mari, and Marwa Mazaid. (2011). “Opening Closed Regimes: What Was the Role of Social Media During the Arab Spring?” Working paper 2011.1, Project on Information Technology and Political Islam (posted April 17, 2015; last revised September 5, 2015).

https:/papers.ssrn.com/sol3/papers.cfm?abstract_id=2595096

Kay, Chris, and C. Spillane. 2013. "Nigerian Smartphone Boom Challenges Nokia Africa

Dominance." Bloomberg, May 28. http://www.bloomberg.com/news/2013-05-

27/nigerian-smartphone-boom-sees-nokia-african-dominance-challenged.html

(accessed July 9, 2017).

Mitchell, Timothy. 2011. Carbon Democracy: Political Power in the Age of Oil. London: Verso Books.

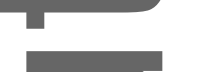

Ogbu, Ahamefula. 2010. “Jonathan: Demand for Free Polls Unstoppable, Plans Facebook Account for Reforms Debate," Thisday Newspapers, May 16.

Ong, Aihwa. 1996. "Cultural Citizenship as Subject-Making: Immigrants Negotiate Racial and Cultural Boundaries in the United States." Cultural Anthropology 37 (5): 737-62. 
1999. Flexible Citizenship: The Cultural Logics of Transnationality. Durham, NC:

Duke University Press.

Pype, Katrien. 2016. “'(Not) Talking like a Motorola': Mobile Phone Practices and Politics of Masking and Unmasking in Postcolonial Kinshasa." Journal of the Royal

Anthropological Institute no. 22, 633-52.

Rogers, Douglas. 2014. "Petrobarter: Oil, Inequality, and the Political Imagination in and aften the Cold War, Current Anthropology." 55 (2): 131-53.

Rosaldo, Renato. 1994. "Cultural Citizenship in San Jose, California.” POLAR: Political and Legal Anthropology Review 17 (2): 57-64.

Rosaldo, Renato, ed. 2003. Cultural Citizenship in Island and Southeast Asia: Nation and Belonging in the Hinterlands. Berkeley: University of California Press.

Ross, Michael L. 1999. “The Political Economy of the Resource Curse.” World Politics 51 (2): 297-322. doi: $10.1017 / \mathrm{s} 0043887100008200$

Shever, Elana. 2012. Resources for Reform: Oil and Neoliberalism in Argentina. Palo Alto, CA:Stanford University Press

Shirky, Clay. 2011. "The Political Power of Social Media: Technology, the Public Sphere, and Political Change." Foreign Affairs, January/February.

Sawyer, Suzana. 2004. Crude Chronicles: Indigenous Politics, Multinational Oil, and Neoliberalism in Ecuador. Durham, NC: Duke University Press.

Smith, Daniel Jordan. 2007. A Culture of Corruption: Everyday Deception and Popular Discontent in Nigeria. Princeton, NJ: Princeton University Press.

Sommers, M. 2011. "Governance, Security and Culture: Assessing Africa's Youth Bulge." International Journal of Conflict and Violence 5 (2): 292-303. 
Soysal, Levent. 2010. “Intimate Engagements of the Public Kind.” Anthropological

Quarterly 83 (2): 373-99.

ski, Irina, and Bjarki Valtyss

Shklovski, Irina, and Bjarki Valtysson. 2012 "Secretly Political: Civic Engagement in Online Publics in Kazakhstan.” Journal of Broadcasting \& Electronic Media 56 (3): 417-33.

Stein, Rebecca L. 2012. "StateTube: Anthropological Reflections on Social Media and The

Israeli State." Anthropological Quarterly 85 (3): 893-916.

Turner, Simon. 2008. "Cyberwars of Words: Expressing the Unspeakable in Burundi's

Diaspora" Journal of Ethnic and Migration Studies 34 (7): 1161-80.

Watts, Michael. 2012. A Tale of Two Gulfs: Life, Death and Dispossession Along Two Oil

Frontiers. American Quarterly 64 (3): 437-67.

Watts, Michael J.2007. "Imperial Oil: The Anatomy of a Nigerian Oil Insurgency." ERKUNDE 62 (1): 27-39.

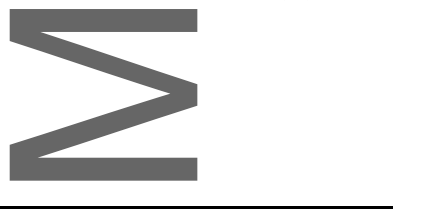

${ }^{1}$ Comment on Goodluck Jonathan's Facebook page, June 28, 2010 at 3:29 am, accessed

October 8,2014, https://www.facebook.com/jonathangoodluck.

2 “Goodluck Jonathan: The Facebook President," George Webster, CNN, October 1, 2010, http://edition.cnn.com/2010/TECH/social.media/10/01/goodluck.jonathan.facebook.profile/in dex.html, accessed October 21, 2014.

3 “Nigeria's President Yar'Adua Dies," May 5, 2010, Aljazeera, http://www.aljazeera.com/news/africa/2010/05/20105523627997165.html, accessed October 1,2014 
4 “Nigeria's Sickly Leader, Umaru Yar'adua, to be Flown Out for Medical Treatment," November 22, 2009, Sahara Reporters, http://saharareporters.com/2009/11/22/nigerias-sickly-leader-umaru-yaradua-be-flown-outmedical-treatment, accessed October 1, 2014.

${ }^{5}$ Danladi Nmod, "A Sick President and the Succession Crisis," News Dairy,

\section{-}

http://www.newsdiaryonline.com/sucess_cris.htm (page discontinued), accessed September $28,2014$.

6 “The Constifutional Crisis in Nigeria," January 30, 2010, Save Nigeria Group, http://savenigeriagroup.com/2010/01/30/sng-press-release-the-constitutional-crisis-in-nigeria, accessed October 1, 2014.

${ }^{7}$ For more, see the 1999 Constitution of the Federal Republic of Nigeria, Chapter VI, Sections 135-141. http://www.nigeria-law.org/ConstitutionOfTheFederalRepublicOfNigeria.htm, accessed June 10, 2017. ${ }^{8}$ Jonathan holds a Bachelor of Science in Zoology, a Master of Science in Hydrobiology/Fisheries Biology, and a doctorate in Zoology, all from the University of Port Harcourt

9 “CIA WorldFact Book: Nigeria,” Central Intelligence Agency, https://www.cia.gov/library/publications/theworld-factbook/geos/ni.html, accessed May 5, 2016.

10 "Nigeria: Internet Use and Telecommunications Report," Internet World Stats, http://www.internetworldstats.com/af/ng.htm, accessed August 18, 2016.

${ }^{11}$ Comment on Goodluck Jonathan's Facebook page, June 28, 2010 at 3:33am, accessed August 16, 2016, https://www.facebook.com/jonathangoodluck.

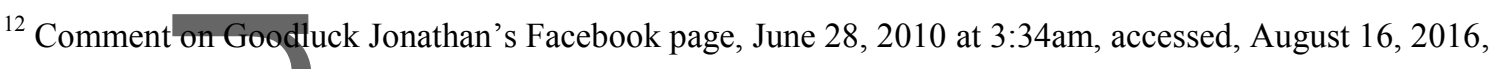
https://www.facebook.com/jonathangoodluck.

${ }^{13}$ For purposes of accuracy, spelling and grammatical errors of posts have not been changed. Comment on Goodluck Jonathan's.Facebook page, June 28, 2010 at 3:36am, accessed August 16, 2016, https://www.facebook.com/jonathangoodluck. 
${ }^{14}$ Comment on Goodluck Jonathan's Facebook page, June 28, 2010, at 3:40am, accessed August 26, 2016, https://www. facebook.com/jonathangoodluck.

${ }^{15}$ Comment on Goodluck Jonathan's Facebook page, June 28, 2010, at 3:41am, accessed September 15, 2014, https://www.facebook.com/jonathangoodluck.

16 “Nigeria: Country Profile,” UNESCO, http://en.unesco.org/countries/nigeria, accessed August 26, 2016.

${ }^{17}$ Comment on Goodluck Jonathan's Facebook page, June 28, 2010 at 3:43am, accessed September 15, 2014, https://www. aacebook.com/jonathangoodluck.

${ }^{18}$ Comment on Goodluck Jonathan's Facebook page, June 29, 2010 at 8:21pm, accessed August 15, 2014, https://www.facebook.com/jonathangoodluck.

${ }^{19}$ The president often signed his posts with his initials, GEJ. Comment on Goodluck Jonathan's Facebook page, September 30,2011 at 3:30pm, accessed August 20, 2015, https://www.facebook.com/jonathangoodluck.

${ }^{20}$ Comment-on Goodluck Jonathan's Facebook page, February 14, 2011 at 7:20pm, accessed August 20, 2015, https://www.facebook.com/jonathangoodluck.

21 “Goodluck Jonathan: The Facebook President,” George Webster, CNN, October 1, 2010, 

http://edition.cnn.com/2010/TECH/social.media/10/01/goodluck.jonathan.facebook.profile/in dex.html, accessed October 21, 2014. See also Comment on Goodluck Jonathan's Facebook page, August 15, 2014 at 6:15pm, accessed August 15, 2014, https://www facebook.com/notes/goodluck-jonathan/speech-by-president-goodluck-ebelejonathan-declaring-his-candidacy-for-the-pdp-/155774224450221.

${ }^{22}$ Comment on Goodluck Jonathan's Facebook page, September 18, 2010 at 2:15am, accessed August 15, 2015, https://www.facebook.com/jonathangoodluck.

${ }^{23}$ Comment on Goodluck Jonathan’s Facebook page, July 7, 2010 at 4:33 am, accessed Sepetember 10, 2013, https://www.facebook.com/jonathangoodluck. 24 “World Cup 2010: Nigerian President Suspends Team After Poor Showing," David Smith, The Guardian, June 30, 2010, http://www.theguardian.com/football/2010/jun/30/nigeria-football-team-worldcup2010, accessed October 27, 2014. 
25 “World Cup 2010: FIFA Issues Ban Deadline to Nigeria," BBC Sport, July 2, 2010, http://news.bbc.co.uk/sport2/hi/football/world_cup_2010/8780028.stm accessed October 28, 2014.

${ }^{26}$ Comment on Goodluck Jonathan's Facebook page, July 5, 2010 at 5:19am, accessed October 14, 2014,

https://www.facebook.com/jonathangoodluck?rf=158024534247638.

${ }^{27}$ Comment on Goodluck Jonathan's Facebook page, September 23, 2013 at 7:15am, accessed October 14, 2014, https://www.facebook.com/jonathangoodluck.

${ }^{28}$ Comment on Goodluck Jonathan's Facebook page, January 7, 2012 at 6:10pm, accessed October 14, 2014, https://www.facebook.com/jonathangoodluck.

${ }^{29}$ Comment on Goodluck Jonathan's Facebook page, January 7, 2012 at 6:15pm, accessed October 14, 2014, https://www.facebook.com/jonathangoodluck.

${ }^{30}$ Comment on Goodluck Jonathan's Facebook page, January 7, 2012 at 3:35am, accessed October 14, 2014, https://www.facebook.com/jonathangoodluck.

${ }^{31}$ Comment on Goodluck Jonathan's Facebook page, January 7, 2012 at 5:15am, accessed October 20, 2014, https://www.facebook.com/jonathangoodluck

${ }^{32}$ Ditto.

${ }^{33}$ Comment on Goodluck Jonathan's Facebook page, January 7, 2012 7:24am, accessed October 20, 2014, https://www.facebook.com/jonathangoodluck.

${ }^{34}$ Comment on Goodluck Jonathan's Facebook page, January 7, 2012 at 6:45pm, accessed October 20, 2014, https://www.facebook.com/jonathangoodluck.

${ }^{35}$ See http://www.omojuwa.com.

${ }^{36}$ Ogundamisi is a political activist and blogger, and is the former host of the British-Nigerian talk show

"Politricks with KO."

${ }^{37}$ See for example https://www.facebook.com/groups/1375404512757711, accessed September 2, 2017.

38 "Tolu Ogunlesi, Appointed Special Assistant on Digital/New Media to the President," Premium Times, February 18, 2016, http://www.premiumtimesng.com/news/more- 
news/198671-buhari-appoints-tolu-ogunlesi-head-new-media-team.html, accessed August 17, 2016.

39 "Buhari Appoints Personal Assistant on New Media," Mohammed Lere, Premium Times, $\square$

February 1, 2016, http://www.premiumtimesng.com/news/more-news/198326-buhariappoints-personal-assistant-on-new-media.html, accessed September 16, 2016.

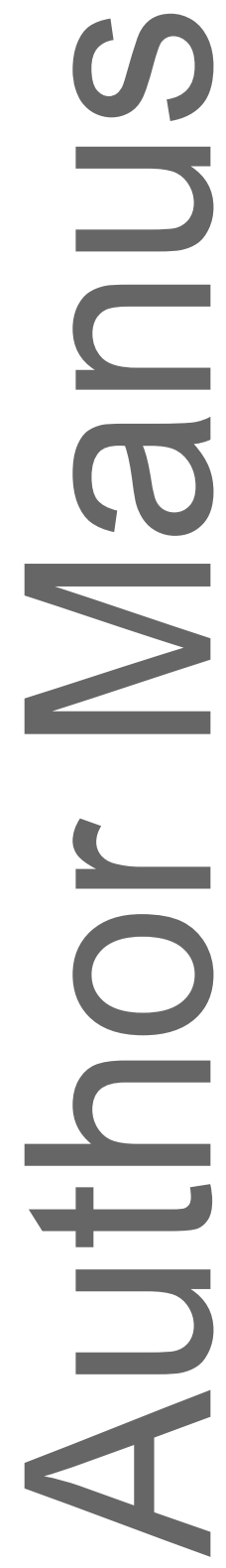

